\title{
MLL/ARHGAP26 Fusion Gene
}

National Cancer Institute

\section{Source}

National Cancer Institute. MLL/ARHGAP26 Fusion Gene. NCI Thesaurus. Code C99337.

A fusion gene that results from a chromosomal translocation $\mathrm{t}(5 ; 11)(\mathrm{q} 31 ; \mathrm{q} 23)$ which

fuses the 5 ' half of the MLL gene to intron 12 of the ARHGAP26 gene. This

rearrangement is associated with juvenile myelomonocytic leukemia. 